\title{
POTENTIALLY BIOACTIVE VOLATILE COMPOUNDS OF SOME EPIPHYLLUM, HYLOCEREUS AND OPUNTIA SPECIES (CACTACEAE FAMILY) CULTIVATED IN CENTRAL EUROPE AND THEIR HS- SPME GC-MS ANALYSIS
}

\author{
SZILVIA CZIGLE ${ }^{1 *}$, MICHAELA BARKOCIOVÁ ${ }^{1}$, ÉVA HÉTHELYI B. ${ }^{2}$, ANNAMARIA \\ PALLAG $^{3}$, ANDREA BÖSZÖRMÉNYI ${ }^{2}$, ANTONIOS KOUTSOULAS ${ }^{1}$, JAROSLAV TÓTH ${ }^{1}$, \\ PAVEL MUČAJI ${ }^{1}$ \\ ${ }^{1}$ Comenius University in Bratislava, Faculty of Pharmacy, Department of Pharmacognosy and Botany, 10 Odbojárov Street, \\ SK-832 32, Bratislava, Slovak Republic \\ ${ }^{2}$ Semmelweiss University, Faculty of Pharmacy, Institute of Pharmacognosy, 26 Üllöi út Street, H-1085, Budapest, Hungary \\ ${ }^{3}$ University of Oradea, Faculty of Medicine and Pharmacy, Department of Pharmacy, 29 Nicolae Jiga Street, RO-410028, \\ Oradea, Romania
}

*corresponding author: szilvia.czigle@uniba.sk

Manuscript received: December 2019

\begin{abstract}
The aim of our work was to analyse volatile compounds obtained from the fruits of three plant genera - Epiphyllum, Hylocereus and Opuntia - using HS-SPME GC-MS (headspace solid phase microextraction gas chromatography - mass spectrometry) methods. In violet Epiphyllum fruits, 12 compounds were identified, the most abundant being 2,3-butane-diol and hexanoic acid. In pink Epiphyllum fruits, 13 compounds were identified, the most abundant being $(E)$-anethol and 1-nonadecene. In green Epiphyllum fruits, 10 compounds were identified, the most abundant being $(E)$-anethol and methyl eugenol. In whitefleshed Hylocereus fruits, 9 compounds were identified, the most abundant being 1-hexadecanol and nonadecane. In redfleshed Hylocereus fruits, 11 compounds were identified, the most abundant being 1-hexadecanol and nonadecane. Analysis of violet Opuntia fruits yielded 12 compounds, the most abundant being nonanal and ethyl decanoate. Analysis of orange Opuntia fruits yielded 8 compounds, the most abundant being ethyl decanoate and (3E)-1,3-octadecadiene.
\end{abstract}

\section{Rezumat}

Scopul lucrării noastre a fost analiza compușilor volatili din fructele obținute de la trei genuri - Epiphyllum, Hylocereus și Opuntia - folosind o metodă HS-SPME GC-MS. În fructele violete de Epiphyllum, au fost identificați 12 compuși, cei mai abundenți fiind 2,3-butan-diolul și acidul hexanoic. În fructele de Epiphyllum roz, au fost identificați 13 compuşi, cei mai abundenți fiind $(E)$-anetolul și 1-nonadecenul. În fructele de Epiphyllum verzi au fost identificați 10 compuși, cei mai abundenți fiind $(E)$-anetolul și metil eugenolul. În fructele de Hylocereus cu mezocarpul alb, au fost identificați 9 compuși, cei mai abundenți fiind 1-hexadecanolul și nonadecanul. În fructele de Hylocereus cu mezocarpul roşu, au fost identificați 11 compuși, cei mai abundenți fiind 1-hexadecanolul și nonadecanul. Prin analiza fructelor violete de Opuntia am obținut 12 compuși, cei mai abundenți fiind nonanalul și decanoatul de etil. Prin analiza fructelor portocalii de Opuntia am obținut 8 compuși, cei mai abundenți fiind decanoatul de etil și (3E)-1,3-octadecadiena.

Keywords: Epiphyllum ssp., Hylocereus ssp., Opuntia ssp., HS-SPME GC-MS

\section{Introduction}

Plant hybrids of the Epiphyllum Haw. genus are cultivated mostly as ornamental plants. Besides, fruits of Epiphyllum hybrids are edible. The genus Hylocereus (Berger) Britt. is famous for its interestingly looking edible fruits (pitaya/pitahaya, or dragon fruit). Opuntia ssp. Mill. fruits (tuna, cactus pears or prickly pears) and cladodes are widely consumed. The fruits can be used as natural colourants safe sources. Main classes of compounds present in this genus include betalains (red betacyanins and yellow betaxanthins), phenolic compounds, triterpenes, sterols, fatty acids, mucilage, vitamins, minerals and fibre $[9,11,14,15,18$,
28, 31, 32]. Current research indicates that these plants possess antioxidant, antiinflammatory, antiproliferative, hepatoprotective, antidiabetic, antihyperlipidaemic, antibacterial, anti-ulcerogenic, neuroprotective, hepatoprotective and diuretic activity and wound healing activities [2, 9, 10, 13-18, 20, 22, 24, 26, 28, 30, 33]. The main objective of this study was to analyse the volatile compounds content and their composition in Epiphyllum ssp., Opuntia ssp. and Hylocereus ssp. fruits (Cactaceae) originating from plants cultivated in the Central Europe. The plant materials were collected from three gardens. This work is part of comprehensive pharmacognostic analyses. The efficient 
FARMACIA, 2020, Vol. 68, 5

potent novel analytical method employed in this study used a combination of headspace solid phase microextraction (HS-SPME) and gas chromatography-mass spectrometry (GC-MS).

\section{Materials and Methods}

\section{Plant material}

Fruits of seven taxa of the Cactaceae family were analysed for the presence and quantity of volatiles. Epiphyllum ssp. Haw. (Hylocereeae tribe) hybrids $(\mathrm{EE} \times \mathrm{EK}-$ violet, $\mathrm{EE} \times \mathrm{EE}-$ pink and $\mathrm{EK} \times \mathrm{EE}-$ green fruits) from a private garden in Modra, SK [11]; Hylocereus (Berger) Britt. (Hylocereeae tribe; $H$. costaricensis - red-fleshed pitaya and $H$. undatus white-fleshed pitaya) from the Botanical Garden in Szeged, HU; Opuntia ssp. Mill. (Opuntieae tribe; $O$. humifusa - violet and $O$. ficus-indica - orange fruits) from the Comenius University Botanical Garden in Bratislava, SK. Ripe fruits were collected in September 2018. The Epiphyllum ssp. and Opuntia ssp. fruits originated from 5-years to 10-years old fruticose plants, and the pitaya/pitahaya (Hylocereus) from arboreous plants. Herbarium samples have been deposited at the Department of Pharmacognosy and Botany (FPHARM CU, SK). At the time of analysis, frozen $\left(-18^{\circ} \mathrm{C}\right)$ fruits were cut into small pieces. They were placed in vials and directly used for HS-SPME GCMS analysis.

Equipment

The composition of volatile compounds was measured by SPME GC-MS [AGILENT 6890/5973N GC/FID (Santa Clara, USA), CTC Combi PAL sampler (CTC Analytics AG, CH)]. Details of the analytical procedures have been published in a recent paper from our laboratory [8].

\section{Results and Discussion}

We determined the volatile compounds' content in fruits of plants of the Epiphyllum, Hylocereus and Opuntia genera cultivated in Central Europe using the HS-SPME GC-MS technique. This method is a relatively new, very sensitive analytical method, particularly when used in pharmacognostic analyses/ control. The benefits of the HS-SPME method in pharmagnostic analysis are: small sample weight, direct handling of fresh, frozen or dry herbal drugs - without the need of hydrodistillation, the possibility to analyse volatile compounds of any plant - not restricted to typical essential oil bearing plants. The sensitivity of the GS-MS method is very good. Results of the HSSPME GC-MS analyses are summarized in Table I.

Table I

Percentage compositions of volatile oil components of Epiphyllum ssp., Hylocereus ssp. and Opuntia ssp.

\begin{tabular}{|c|c|c|c|c|c|c|c|c|c|}
\hline $\left.\begin{array}{c}\text { RT } \\
{[\mathrm{min}]}\end{array}\right]$ & Essential oil compounds & KI & $\begin{array}{l}\text { EV } \\
{[\%]}\end{array}$ & $\begin{array}{c}\text { EP } \\
{[\%]}\end{array}$ & $\begin{array}{l}\text { EG } \\
{[\%]}\end{array}$ & $\begin{array}{l}\text { HW } \\
{[\%]}\end{array}$ & $\begin{array}{l}\text { HR } \\
{[\%]}\end{array}$ & $\begin{array}{l}\text { OV } \\
{[\%]}\end{array}$ & $\begin{array}{l}\text { OO } \\
{[\%]}\end{array}$ \\
\hline 3.23 & 2,3-butanediol & 773 & $27.1 \pm 0.2$ & - & - & - & - & - & - \\
\hline 3.34 & unknown & 820 & - & - & - & - & - & $3.1 \pm 0.2$ & - \\
\hline 7.31 & ethyl hexanoate & 998 & - & - & - & - & - & $2.0 \pm 0.1$ & $6.3 \pm 0.5$ \\
\hline 7.43 & 1-octanol & 1068 & - & - & - & - & - & $7.4 \pm 0.6$ & - \\
\hline 9.55 & nonanal & 1100 & - & - & - & - & - & $43.5 \pm 2.1$ & $11.8 \pm 1.0$ \\
\hline 9.62 & cis-rose oxide & 1108 & $2.1 \pm 0.1$ & $1.1 \pm 0.1$ & $9.0 \pm 0.7$ & - & - & - & - \\
\hline 11.35 & ethyl octanoate & 1196 & - & - & - & - & - & - & $5.1 \pm 0.4$ \\
\hline 11.46 & $\alpha$-terpineol & 1186 & $1.9 \pm 0.1$ & - & $6.7 \pm 0.5$ & - & - & - & - \\
\hline 12.06 & neral & 1238 & - & $1.6 \pm 0.1$ & - & - & - & - & - \\
\hline 12.41 & geraniol & 1249 & - & $11.7 \pm 0.1$ & - & - & - & - & - \\
\hline 12.71 & orcinol dimethyl ether & 1259 & - & $2.3 \pm 0.2$ & - & - & - & - & - \\
\hline 14.61 & $(3 E)-1,3$-octadecadiene & 1267 & - & - & - & - & - & - & $21.9 \pm 2.0$ \\
\hline 13.09 & $(E)$-anethol & 1282 & $0.6 \pm 0.0$ & $28.1 \pm 2.2$ & $20.5 \pm 2.0$ & - & - & - & - \\
\hline 14.86 & ethyl decanoate & 1395 & - & - & - & - & - & $12.1 \pm 1.1$ & $35.1 \pm 3.2$ \\
\hline 15.88 & unknown & 1495 & - & - & - & - & $1.4 \pm 0.1$ & - & - \\
\hline 16.61 & methyl eugenol & 1403 & $0.5 \pm 0.0$ & - & $14.7 \pm 1.1$ & - & - & - & - \\
\hline 16.65 & (Z)-methyl isoeugenol & 1459 & - & - & - & - & - & $1.1 \pm 0.1$ & - \\
\hline 17.95 & dimethyl ionone & 1565 & - & - & - & - & $1.1 \pm 0.1$ & - & - \\
\hline 18.03 & ethyl dodecanoate & 1595 & - & - & - & - & - & $4.0 \pm 0.3$ & $10.6 \pm 1.0$ \\
\hline 18.35 & unknown & 1609 & - & - & - & - & - & $3.3 \pm 0.2$ & - \\
\hline 19.08 & unknown & 1620 & - & - & - & $1.7 \pm 0.1$ & $0.7 \pm 0.0$ & - & - \\
\hline 19.16 & 1-heptadecene & 1689 & $1.1 \pm 0.1$ & $2.0 \pm 0.2$ & - & - & - & - & - \\
\hline 19.46 & heptadecane & 1700 & - & $2.3 \pm 0.2$ & - & $3.0 \pm 0.3$ & $3.6 \pm 0.3$ & - & - \\
\hline 19.56 & unknown & 1638 & - & - & - & - & - & $3.1 \pm 0.2$ & - \\
\hline 19.81 & unknown & 1356 & - & - & - & $0.8 \pm 0.0$ & $1.0 \pm 0.0$ & - & - \\
\hline 20.74 & unknown & 1699 & - & - & - & - & - & $3.0 \pm 0.1$ & - \\
\hline 21.43 & 3,4,5-trimethoxy benzoic acid & 1771 & - & $6.5 \pm 0.4$ & - & - & - & - & - \\
\hline
\end{tabular}


FARMACIA, 2020, Vol. 68, 5

\begin{tabular}{|c|c|c|c|c|c|c|c|c|c|}
\hline \hline $\begin{array}{c}\text { RT } \\
{[\mathbf{m i n}]}\end{array}$ & Essential oil compounds & KI & $\begin{array}{c}\text { EV } \\
{[\%]}\end{array}$ & $\begin{array}{c}\text { EP } \\
{[\%]}\end{array}$ & $\begin{array}{c}\text { EG } \\
{[\%]}\end{array}$ & $\begin{array}{c}\text { HW } \\
{[\%]}\end{array}$ & $\begin{array}{c}\text { HR } \\
{[\%]}\end{array}$ & $\begin{array}{c}\text { OV } \\
{[\%]}\end{array}$ & $\begin{array}{c}\text { OO } \\
{[\%]}\end{array}$ \\
\hline 21.62 & hexahydrofarnesyl acetone & 1845 & - & $3.9 \pm 0.3$ & - & - & - & - & - \\
\hline 21.93 & 1-hexadecanol & 1874 & - & - & - & $64.2 \pm 5.0$ & $63.7 \pm 5.3$ & - & - \\
\hline 22.07 & 1-nonadecene & 1891 & $5.4 \pm 0.5$ & $14.0 \pm 1.2$ & - & $7.2 \pm 0.6$ & $6.8 \pm 0.5$ & - & - \\
\hline 22.35 & nonadecane & 1900 & - & $3.8 \pm 0.3$ & - & $7.8 \pm 0.6$ & $8.0 \pm 0.6$ & - & - \\
\hline 22.81 & methyl hexadecanoate & 1921 & - & - & - & $6.00 \pm 0.5$ & $6.3 \pm 0.5$ & - & - \\
\hline 23.43 & hexadecanoic acid & 1959 & $15.2 \pm 1.2$ & $10.2 \pm 1.0$ & $7.0 \pm 0.6$ & $2.00 \pm 0.2$ & $1.6 \pm 0.1$ & $9.4 \pm 0.8$ & $3.9 \pm 0.3$ \\
\hline 23.92 & ethyl hexadecanoate & 1993 & $10.4 \pm 0.9$ & - & $13.2 \pm 1.2$ & - & - & & \\
\hline 25.23 & 1-octadecanol & 2077 & - & - & - & - & - & - & - \\
\hline 25.35 & heneicosane & 2100 & $2.9 \pm 0.2$ & $3.4 \pm 0.3$ & $3.8 \pm 0.3$ & - & $3.5 \pm 0.3$ & - & - \\
\hline 25.41 & 1-eicosanol & 2276 & - & - & - & $4.2 \pm 0.3$ & - & - & - \\
\hline 26.12 & linoleic acid methyl ester & 2092 & - & - & - & - & - & $4.2 \pm 0.3$ & $4.4 \pm 0.3$ \\
\hline 26.22 & linoleic acid ethyl ester & 2155 & $8.4 \pm 0.7$ & - & $7.5 \pm 0.6$ & - & - & - & - \\
\hline 26.34 & ethyl oleate & 2185 & $17.8 \pm 1.5$ & - & $12.7 \pm 1.1$ & - & - & - & - \\
\hline & Total identified & & $\mathbf{9 3 . 4}$ & $\mathbf{9 . 9}$ & $\mathbf{9 5 . 1}$ & $\mathbf{9 6 . 9}$ & $\mathbf{9 7 . 4}$ & $\mathbf{9 6 . 2}$ & $\mathbf{9 8 . 3}$ \\
\hline
\end{tabular}

RT - retention time; KI - Kovats' retention index (obtained by GC-MS in this study using a DB-5MS column); EV - violet Epiphylli fructus; $\mathrm{EP}$ - pink Epiphylli fructus; EG - green Epiphylli fructus; HW - white-fleshed Hylocerei fructus, $\mathrm{HR}$ - red-fleshed Hylocerei fructus; $\mathrm{OV}$ - violet Opuntiae fructus; $\mathrm{OO}$ - orange Opuntiae fructus

Three Epiphyllum ssp. cactus hybrids were analysed with violet, pink and green fruits. Volatile compounds analysis of the violet Epiphylli fructus (Figure 1) resulted in the identification of 12 constituents. Most abundant compounds were 2,3-butanediol, hexanoic acid, and ethyl hexadecanoate with a percentage of 27.1, 15.2 and 10.4, respectively. In the pink Epiphylli fructus, 13 compounds were identified. Most abundant were $(E)$-anethol, 1-nonadecene and geraniol, with a percentage of 28.1, 14.0 and 11.7, respectively. Nine compounds were identified in the green Epiphylli fructus. Most abundant compounds were (E)-anethol, methyl eugenol and ethyl hexadecanoate with a percentage of 20.5, 14.7 and 13.2, respectively. The comparison between three hybrids showed 4 compounds were present in all of them, namely cis-rose oxide, $(E)$-anethol, hexadecanoic acid, and heneicosane (Table I). There are very few scientific studies investigating the phytochemistry of Epiphyllum ssp. secondary metabolites. To our knowledge, none of these studies examined volatile compounds of the fruits of these plants.

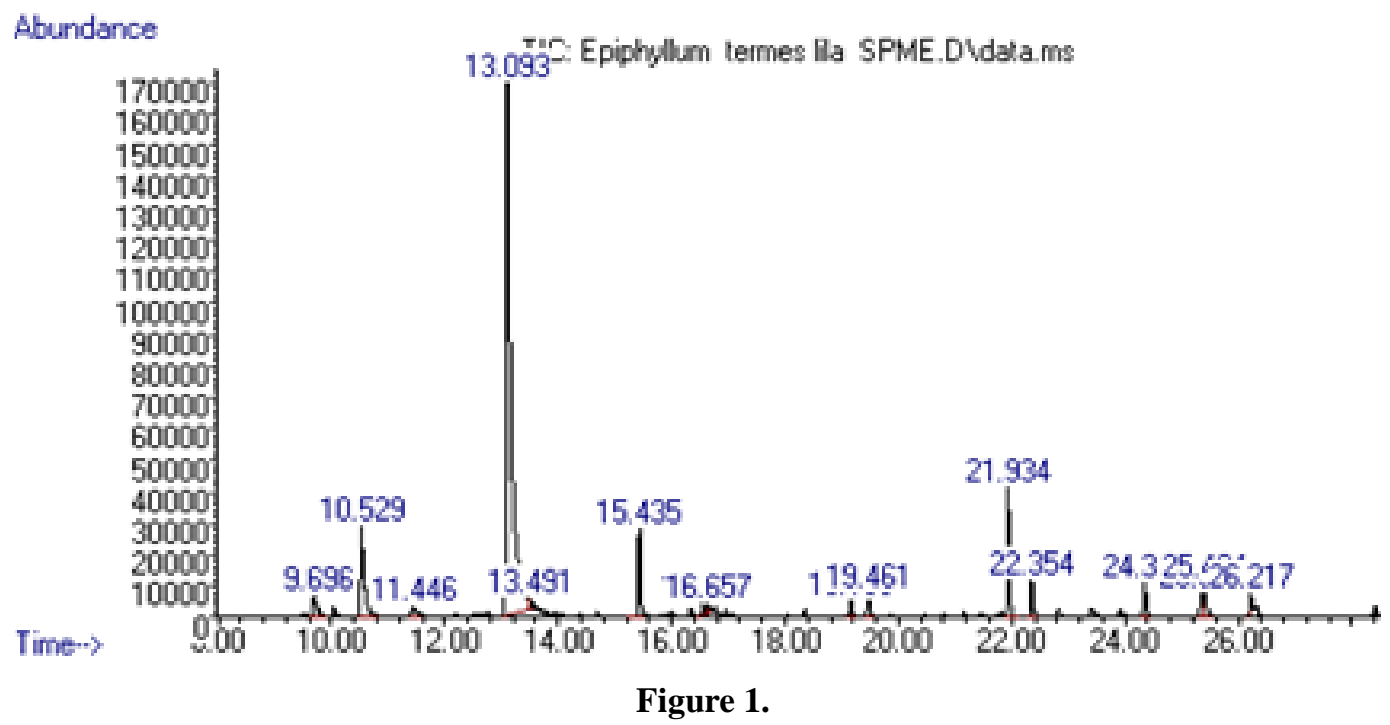

GC chromatogram of Epiphyllum ssp. violet fruits

Two Hylocereus species, H. undatus (white-fleshed pitaya) and $H$. costaricensis (red-fleshed pitaya) were analysed separately. In $H$. undatus fruits, 9 volatile compounds were identified, namely 1 -hexadecanol, with a percentage of 64.2 , nonadecane, with a percentage of 7.8, 1 nonadecene, with a percentage of 7.2. Volatile compounds analysis of $H$. costaricensis fruits resulted in the identification of 11 constituents. Most abundant compounds were 1-hexadecanol, with a percentage of 63.7 , nonadecane, with a percentage of 8.0, 1-nonadecene, with a percentage of 6.8. There are few studies addressing volatile compounds analysis in Hylocereus ssp. stems [25], flowers [27], peels [19], fruits [23], and seeds [4]. According to a literature 
search, only a few studies investigating volatile constituents of the Hylocereus genus have been published so far. Obenland et al. [21] studied the impact of storage conditions and variety on aromatic Hylocereus spp. volatiles by SPME GC-MS. Six varieties of pitahaya fruits (three $H$. costarensis, one $H$. polyrhizus $\times H$. undatus and one $H$. undatus were examined in the study, and 34 aroma volatiles were identified. 2-Hexenal was the most prevalent aldehyde. Other identified compounds were hydrocarbons, alcohols, a ketone, an ester and a furan. We identified an alcohol, 1-hexadecanol, in our whitefleshed Hylocerei fructus (H. undatus) and red-fleshed Hylocerei fructus (H. costarensis) as the major compound - $64.2 \%$ and $63.7 \%$, respectively, alongside the hydrocarbon nonadecane $-7.8 \%$ and $8.0 \%$ (Table I). Luo et al. [19] used SFE and GC-MS analysis to determine the chemical composition of $H$. polyrhizus and $H$. undatus fruit peel. 24 compounds were identified in $H$. polyrhizus peel extract, mostly triterpenoids (29.77\%) and steroids (16.46\%). The most abundant compounds were $\beta$-amyrin (15.87\%), $\alpha$-amyrin $(13.90 \%$ ) and octacosane (12.2\%). As for H. undatus peel, 19 compounds were identified, mostly triterpenoids $(23.39 \%)$ and steroids (19.32\%) as well. Most abundant compounds were $\beta$-amyrin (23.39\%), $\gamma$-sitosterol $(19.32 \%)$ and octadecane $(9.25 \%)$. Their analysis also showed 1nonadecene with a percentage of 3.17 in the fruit peel of $H$. polyrhizus. According to our results, it was also present in $H$. costaricensis, with a percentage of 6.8 (Table I). Another study was conducted by Célis et al. [6] on Hylocereus megalanthus, yellow pitaya fruits. A total of 121 volatile constituents were identified. The most abundant compounds were 2-hexenal (5.1\%) and $\gamma$-cadinene $(4.7 \%)$. This study also revealed the presence of heptadecane and nonadecane, which were identified in our analyses as well (Table I), $H$. undatus: $3.0 \%$ and $7.8 \%$, respectively, $H$. costaricensis: $3.6 \%$ and $8.0 \%$ ). Analysis of volatile compounds in pitaya flowers undertaken by Shen et al. [27] revealed 49 volatile compounds by HS-SPME GC-MS methods, too. Most abundant were sesquiterpenes and their oxidized derivates $(27.78 \%)$, alkanes $(25.14 \%)$ and esters $(14.40 \%)$.

The fruits of two Opuntia ssp. taxa were analysed violet and orange. Analysis of the violet fruit resulted in the identification of 8 constituents. Most abundant compounds were nonanal, ethyl decanoate and hexadecanoic acid, with a percentage of 43.5, 12.1 and 9.4, respectively. Analysis of the orange fruit resulted in the identification of 8 constituents. Most abundant compounds were ethyl decanoate, (3E)-1,3-octadecadiene and nonanal with a percentage of 35.1, 21.1 and 11.8 , respectively. The comparison between the two taxa showed that 6 compounds were present in both of them, namely ethyl hexanoate, nonanal, ethyl decanoate, ethyl dodecanoate, hexadecanoic acid and linoleic acid methyl ester. Volatile compounds composition has been studied in Opuntia ssp. cladodes, flowers, fruits and seeds [3, 7, 9, 12, 14, 30, 33]. Arena et al. [3] identified 16 volatile compounds of red, yellow and white prickly pear fruits using GC-MS and GC-FID methods, with 2-hexen-1-ol being the most abundant one with a percentage of 56.8 , followed by hexan-1-ol with a percentage of 26.4. The most important aroma contributors among the identified compounds were (E,Z)-2,6-nonadien-1-ol and 2-methylbutanoic acid methyl ester. The former aroma compound gives the typical odour of prickly pear, while the latter has a fresh fruity odour. The amount of 2methylbutanoate was much higher than that of nonadienol in the white cultivar. Comparison of aroma values of the unripe and ripe fruits confirms these two compounds as the aroma quality factors at ripeness [3]. The complex aroma of the violet and red Opuntiae fructus analysed in our study is the result of several volatile odour types, e.g. apple peel (ethyl hexanoate), grape (ethyl decanoate), citrus (ethyl decanoate, 1nonanal), fruits (ethyl hexanoate, ethyl octanoate), fat (1-nonanal, hexadecanoic acid) and green (1-nonanal) (Table I) [1]. An analysis of $O$. vulgaris fruit juice performed by Essa and Salama [12] resulted in the identification of 12 volatiles, with cyclopentanone and 2-propanol being the most abundant ones. Weckerle et al. [29] concluded that major compounds of the $O$. ficus-indica fruit were (E)-2-hexenal, 1-hexanol, $(E)$-2-hexen-1-ol, $(E)$-2-nonenol and $(E)$ - and (Z)-2,6nonadienol. They also identified nonanal and 1-octanol, which is in agreement with our results (Table I). Another study was conducted by Zito et al. [34] on fruits of two Sicilian cultivars of $O$. ficus-indica. Most abundant compounds in the red cultivar were heptacosane in the peel $(5.5 \%$, while comparably only $1.3 \%$ in the yellow peel), squalene in the pulp (27.2\%, while only $5.3 \%$ in the yellow pulp) and hexadecenoic acid in the seeds $(28.5 \%)$. As for the yellow cultivar, most abundant compounds were hexahydrofarnesyl acetone in the peel (19.1\%, while only $5.4 \%$ in the red peel) and hexadecenoic acid in both the pulp $(65.7 \%$, while only $5.4 \%$ in the red pulp) and seeds $(33.0 \%)$. The yellow fruits pulp also contained methyl linolenate (3.5\%), present in both violet and orange fruits in our analyses ( $4.2 \%$ and $4.4 \%$, respectively) (Table I). Bareh et al. [5] analysed volatiles of prickly pear fresh fruit, juice and jam. 14 compounds were identified, with $(E)$-3-hexen-1-ol and ethyl acetate being the major ones. Oumato et al. [23] studied volatile constituents of three $O$. ficus-indica varieties from Morocco. They identified 46 compounds, where the main constituents in all three varieties were 2-hexenal and 1-hexanol with percentages of $10.6 \%, 10.9 \%$ and $44.0 \%$ for the first compound and $10.3 \%, 5.9 \%$ and $18.7 \%$ for the second one. All three varieties of Moroccan $O$. ficus-indica fruits contained 1-octanol (1.0\%, 0.8\% and $0.2 \%$ ) that was identified in our violet fruits $(7.4 \%)$ and nonanal $(1.4 \%, 2.8 \%$ and $1.1 \%)$ that was identified 
FARMACIA, 2020, Vol. 68, 5

in both violet and orange fruits in our analyses $(43.5 \%$ and $11.8 \%$ ) (Table I) contributing to moss, nut, citrus, mushroom/fat and green odours [1].

\section{Conclusions}

We determined the volatile compounds' content in fruits of plants of the Epiphyllum, Hylocereus and Opuntia genera cultivated in Central Europe using the HS-SPME GC-MS technique. We identified and quantified 19 volatile compounds in Epiphyllum fruits, 14 volatile compounds in Opuntia fruits and 13 volatile compounds in Hylocereus fruits. Our results bring new data in this field of research and partially confirm data of similar studies published so far.

\section{Acknowledgement}

This work was supported by grants: APVV-15-0308, VEGA 2/0115/19, VEGA 1/0359/18, NKFI K 132044, ÚNKP-19-4 and Bolyai Research Scholarship of the HAS. Epiphyllum hybrids samples were a kind gift from the botanical collection of Ol'ga Erdelská (SAS, Bratislava, SK).

\section{Conflict of interest}

The authors declare no conflict of interest.

\section{References}

1. Acree TE, Arn H, Editors, Flavornet and Human Odor Space, Gas chromatography - Olfactometry (GCO) of Natural Products. Geneva, USA: Cornell University, NYSAES, 2004, www.flavornet.org/.

2. Alimirzaloo F, Asgarpanah J, Chemical composition of the volatile oils from the fruits and seeds of the medicinal plant Pycnocycla Aucherana Decne. Ex Boiss. from Iran, Farmacia, 2017; 65(4): 591-595.

3. Arena E, Campisi S, Fallico B, Lanza MC, Maccarone $\mathrm{E}$, Aroma value of volatile compounds of prickly pear (Opuntia ficus indica (L.) Mill. Cactaceae). Ital J Food Sci., 2001; 13(3): 311-319.

4. Ariffin AA, Bakar J, Tan ChP, Rahman RA, Karim R, Loi ChCh, Essential fatty acids of pitaya (dragon fruit) seed oil. Food Chem., 2009; 114(2): 561-564.

5. Bareh GF, Shaheen MS, Hussein AMS, Production of good quality products from Egyptian prickly pear fruits. J Appl Sci Res., 2012; 8(11): 5494-5503.

6. Célis CQ, Gil DE, Pino JA, Characterization of odoractive compounds in yellow pitaya (Hylocereus megalanthus (Haw.) Britton et Rose). Rev CENIC Cienc Quím., 2012; 43: 1-6.

7. Chahdoura H, Barreira JCM, Fernández-Ruiz V, Morales P, Calhelha RC, Flamini G, Soković M, Ferreira ICFR, Achour L, Bioactivity, proximate, mineral and volatile profiles along the flowering stages of Opuntia microdasys (Lehm.): defining potential applications. Food Funct., 2016; 7(3): 1458-1467.

8. Czigle Sz, Héthelyi BÉ, Háznagy-Radnai E, Máthé I, Tóth J, Analysis of Volatile Constituents of Ginkgo Leaf. Nat Prod Commun., 2019; 14(6): 332-339.
9. Dembitsky VM, Poovarodom S, Leontowicz H, Leontowicz M, Vearasilp S, Trakhtenberg S, Gorinstein $\mathrm{S}$, The multiple nutrition properties of some exotic fruits: Biological activity and active metabolites. Food Res Int., 2011; 44(7): 1671-1701.

10. El-Mostafa K, El Kharrassi Y, Badreddine A, Andreoletti P, Vamecq J, El Kebbaj MS, Latruffe N, Lizard G, Nasser B, Cherkaoui-Malki M, Nopal cactus (Opuntia ficus-indica) as a source of bioactive compounds for nutrition, health and disease. Molecules, 2014; 19(9): 14879-14901.

11. Erdelská O, Stintzing F, Phytochemical and morphological evaluation of flowers and fruits from Epiphyllum hybrids during development. Biologia, 2011; 66(5): 821-827.

12. Essa HA, Salama MF, Effect of macerate enzymes on the yield, quality, volatile compounds and rheological property of prickly pear juice. Nahrung., 2002; 46(4): 245-250.

13. Feugang JM, Konarski P, Zou D, Stintzing FC, Zou $\mathrm{CH}$, Nutritional and medicinal use of Cactus pear (Opuntia spp.) cladodes and fruits. Front Bio Sci., 2006; 11(1): 2574-2589.

14. Hamdi M, Nutritional and medicinal uses of prickly pear cladodes and fruits: Processing technology experiences and constraints. In: Hui YH, Editor. Handbook of fruits and fruit processing. Iowa: Blackwell Publishing, 2006.

15. Ibrahim SRM, Mohamed GA, Khedr AIM, Zayed MF, El-Kholy AA-ES, Genus Hylocereus: Beneficial phytochemicals, nutritional importance, and biological relevance - A review. J Food Biochem., 2018; 42(2): $1-9$.

16. Jurca T, Pallag A, Marian E, Mureșan ME, Stan RL, Vicaș LG, The histo-anatomical investigation and the polyphenolic profile of antioxidant complex active ingredients from three Viola Species. Farmacia, 2019; 67(4): 634-640.

17. Jurca T, Baldea I, Filip GA, Olteanu D, Clichici S, Pallag A, Vicas L, Marian E, Micle O, Muresan M, The effect of Tropaeolum majus L. on bacterial infections and in vitro efficacy on apoptosis and DNA lesions in hyperosmotic stress. J Phisiol Pharmacol., 2018; 69(3): 391-401.

18. Le Bellec F, Vaillant F, Imbert E, Pitahaya (Hylocereus spp.): a new fruit crop, a market with a future. Fruits, 2006; 61(4): 237-250.

19. Luo H, Cai Y, Peng Z, Liu T, Yang S, Chemical composition and in vitro evaluation of the cytotoxic and antioxidant activities of supercritical carbon dioxide extracts of pitaya (dragon fruit) peel. Chem Cent J., 2014; 8(1): 1/1-1/7.

20. Marian E, Vicas LG, Tunde Jurca T, Muresan M, Pallag A, Stan RL, Sevastre B, Diaconeasa Z, Ionescu CML, Hangan AC, Salivia officinalis L. and Verbascum phlomoides L. Chemical, Antimicrobial, Antioxidant and Antitumor Investigations. Rev Chim (Bucharest), 2018; 69(2): 445-448.

21. Obenland D, Cantwell M, Lobo R, Collin S, Sievert J, Arpaia ML, Impact of storage conditions and variety on quality attributes and aroma volatiles of pitahaya (Hylocereus spp.). Sci Hort., 2016; 199: 15-22.

22. Onakpoya IJ, O'Sullivan J, Heneghan CJ, The effect of cactus pear (Opuntia ficus-indica) on body weight 
and cardiovascular risk factors: A systematic review and meta-analysis of randomized clinical trials. Nutrition, 2015; 31(5): 640-646.

23. Oumato J, Zrira S, Petretto GL, Saidi B, Salaris M, Pintore G, Volatile constituents and polyphenol composition of Opuntia ficus-indica (L.) Mill from Morocco. Rev Mar Sci Agron Vét., 2016; 4(3): 5-11.

24. Pallag A, Filip GA, Olteanu D, Clichici S, Baldea I, Jurca T, Micle O, Vicaş L, Marian E, Soriţău O, Cenariu M, Mureşan M, Equisetum arvense L. Extract induces antibacterial activity and modulates oxidative stress, inflammation, and apoptosis in endothelial vascular cells exposed to hyperosmotic stress. Hindawi, Oxidat Med Cel Longevity, 2018; Art. ID 3060525: 1-14.

25. Qingzhi M, Furuta Y, Daochun Q, Dangquan Z, Molecular characteristics of extractives of Hylocereus undulates stems. Pak J Pharm Sci., 2015; 28(2): 681-685.

26. Sharifi-Rad J, Ayatollahi SA, Varoni EM, Salehi B, Kobarfard F, Sharifi-Rad M, Iriti M, Sharifi-Rad M, Chemical Composition and Functional Properties of Essential Oils from Nepeta schiraziana Boiss. Farmacia, 2017; 65(5): 802-812.

27. Shen L, Lei F, Analysis of volatile components in pitaya flower by headspace solid phase microextractionGC/MS. Food Sci., 2010; 31(22): 315-317.
28. Stintzing FC, Carle R, Cactus stems (Opuntia spp.): A review on their chemistry, technology, and uses. Mol Nutr Food Res., 2005; 49(2): 175-194.

29. Weckerle B, Bastl-Borrmann R, Richling E, Hor K, Ruff Ch, Schreier P, Cactus pear (Opuntia ficus indica) flavour constituents - chiral evaluation (MDGC MS) and isotope ratio (HRGC-IRMS) analysis. Flavour Fragr J., 2001; 16(5): 360-363.

30. Wright CR, Setzer WN, Chemical composition of volatiles from Opuntia littoralis, Opuntia ficus-indica, and Opuntia prolifera growing on Catalina Island, California. Nat Prod Res., 2013; 28(3): 208-211.

31. Wu B, Lin W, Studies on chemical constituents of Epiphyllum oxypetalum. Chin Pharm J., 2010; 45: 496-499.

32. Wybraniec S, Stalica P, Spórna A, Mizrahi Y, Profiles of betacyanins in epidermal layers of grafted and light-stressed cacti studied by LC-DAD-ESI-MS/MS. J Agric Food Chem., 2010; 58(9): 5347-5354.

33. Xu F, Wang Y, Wu H, Wang X, Determination of the volatiles in Opuntia dillenii by headspace solidphase microextraction and gas chromatography-mass spectrometry. Instrum Sci Tech., 2015; 43(4): 446-452.

34. Zito P, Sajeva M, Bruno M, Rosselli S, Maggio A, Senatore F, Essential oils composition of two Sicilian cultivars of Opuntia ficus-indica (L.) Mill. (Cactaceae) fruits (prickly pear). Nat Prod Res., 2012; 27(14): 1305-1314. 